Volume 10 Issue 1, January-March 2016: pp. 1-220. Copyright (c) 2015-2016 FIAT JUSTISIA. Faculty of Law, Lampung University, Bandarlampung, Lampung, Indonesia. ISSN: 1978-5186 | e-ISSN: 2477-6238.

Open Access: http://jurnal.fh.unila.ac.id/index.php/fiat

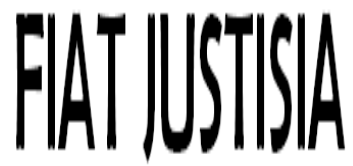

Fiat Justisia is licensed under a Creative Commons Attribution 4.0 International License, which permits unrestricted use, distribution, and reproduction in any medium, provided the original work is properly cited.

\title{
PERTANGGUNGJAWABAN PIDANA TERHADAP PELAKU TINDAK PIDANA PEMILU LEGISLATIF TAHUN 2014 (Studi Putusan Nomor: 70/Pid./2014/PT.TJK.)
}

\section{The Criminal Liability of the Perpetrators of Criminal Acts Legislative Elections 2014 (Study Decision Number: 70/Pid./2014/PT.TJK.)}

\author{
Selvi Yuliyanti \\ Komisi Pemilihan Umum Daerah (KPUD) Kabupaten Way Kanan, \\ Provinsi Lampung \\ email: selviyuliyanti10@yahoo.co.id
}

\begin{abstract}
The criminal responsibility of the perpetrators of criminal acts of legislative elections in 2014 in Decision No. 70/Pid./2014/PT.TJK based on the presence of errors and intentional element in the commission of a crime, the defendant's ability to be responsible, there is no justification and forgiving for the defendant in committing criminal offenses legislative elections, by deliberately adding voice to a certain election participants. The judges convict the Defendants therefore with imprisonment for 3 (three) months, and a fine IDR 500.000 (five hundred thousand rupiahs) provided that if the fine is not paid then replaced with imprisonment for 1 (one) month. Basic legal considerations judges in imposing criminal offense to legislative elections in 2014 juridically is the fulfillment of the evidence in the trial referred to in Article 183 and Article 184 Criminal Procedure Code. Philosophically considered that the criminal as a guidance to the behavior of the accused. Sociologically consists of aggravating factors, namely the defendant as the election organizer has injured the implementation of democracy and the mitigating circumstances that the defendants confessed and has not been convicted, have family responsibilities and polite during the trial.
\end{abstract}

Keywords: Criminal Liability, Election, Legislative 


\begin{abstract}
Abstrak
Pertanggungjawaban pidana terhadap pelaku tindak pidana Pemilu Legislatif Tahun 2014 didasarkan dengan adanya unsur kesalahan dan kesengajaan dalam melakukan perbuatan pidana, kemampuan terdakwa untuk bertanggungjawab, tidak ada alasan pembenar dan pemaaf bagi terdakwa dalam melakukan tindak pidana Pemilu Legislatif, yaitu dengan sengaja melakukan penambahan suara kepada Peserta Pemilu tertentu. Majelis hakim menjatuhkan pidana kepada para terdakwa oleh karena itu dengan pidana penjara selama 3 (tiga) bulan, dan denda sebesar Rp500.000,- (lima ratus ribu rupiah) dengan ketentuan apabila denda tersebut tidak dibayar maka diganti dengan pidana kurungan selama 1 (satu) bulan.Dasar pertimbangan hukum hakim dalam menjatuhkan pidana terhadap pelaku tindak pidana Pemilu Legislatif Tahun 2014 dalam Putusan Nomor 70/Pid./2014/PT.TJK secara yuridis adalah terpenuhinya alat-alat bukti dalam persidangan sebagaimana dimaksud Pasal 183 dan Pasal 184 KUHAP. Secara filosofis adalah menilai bahwa pidana yang dijatuhkan sebagai upaya pembinaan terhadap perilaku terdakwa. Secara sosiologis terdiri dari hal yang memberatkan yaitu para terdakwa sebagai penyelenggara pemilu telah menciderai pelaksanaan demokrasi dan hal yang meringankan yaitu para terdakwa mengakui perbuatannya dan belum pernah dihukum, memiliki tanggungan keluarga dan sopan dalam persidangan
\end{abstract}

\title{
Kata Kunci: Pertanggungjawaban Pidana, Pemilu, Legislatif
}

\section{A. Pendahuluan}

Pemilihan Umum (Pemilu) Legislatif pada dasarnya merupakan sarana pelaksanaan kedaulatan rakyat dalam Negara Kesatuan Republik Indonesia yang berdasarkan Pancasila dan Undang-Undang Dasar Negara Republik Indonesia Tahun 1945. Pemilu Legislatif diselenggarakan untuk memilih anggota Dewan Perwakilan Rakyat (DPR), Dewan Perwakilan Daerah (DPD), Dewan Perwakilan Rakyat Daerah (DPRD) Provinsi, dan DPRD Kabupaten/Kota yang berasal dari partai politik. Pemilihan para wakil rakyat yang akan duduk di lembaga legislatif ini merupakan perwujudan dari demokrasi Indonesia yang menganut sistem kepartaian melalui partai politik.

Pemilihan para calon anggota legislatif dari partai politik secara langsung, mengindikasikan bahwa suara rakyat adalah penentu dalam penyelenggaraan pemerintahan dan kehidupan politik, karena partai politik sebagai penyalur aspirasi rakyat. Upaya yang lebih penting lagi adalah untuk memberdayakan partai politik, agar partai lebih kuat dan mandiri, sehingga melahirkan kebijakan partai yang berorientasi pada kepentingan rakyat. Rakyat dalam wacana negara demokrasi menjadi titik sentral karena pada 
hakikatnya demokrasi adalah pemerintahan yang dilaksanakan dari, oleh dan untuk rakyat.

Pemilu memiliki arti penting dalam negara demokrasi, karena berkaitan dengan tiga fungsi utamanya yaitu (1) Legitimasi politik, Melalui Pemilu, legitimasi pemerintah atau penguasa dikukuhkan karena pemerintah terpilih hakikatnya adalah pilihan rakyat terbanyak yang memiliki kedaulatan. (2) Sirkulasi elit politik. Dengan Pemilu, terjadinya sirkulasi atau pergantian elit kekuasaan dilakukan secara lebih adil, karena warga negaralah yang langsung menentukan siapa yang masih dianggap memenuhi syarat sebagai elit politik dan siapa yang tidak. (3) Pendidikan politik. Pemilu berfungsi sebagai alat untuk melakukan pendidikan politik bagi warga negara agar dapat memahami hak dan kewajiban politiknya. Dengan keterlibatan dalam proses pelaksanaan Pemilu, diharapkan warga negara akan mendapat pelajaran langsung tentang bagaimana selayaknya warga negara berkiprah dalam sistem demokrasi. ${ }^{1}$

Konteks sistem pemilu dan sistem kepartaian tidak terlepas dari sistem pemerintahan suatu negara. Sistem pemerintahan mempengaruhi cara atau metode seseorang dalam memperoleh kekuasan tertinggi maupun jabatan strategis lainnya. Pada sistem pemerintahan demokrasi kekuasaan diperoleh melalui sistem pemilihan umum dengan beberapa partai yang mengikutinya, kekuasaan berada di tangan rakyat. Rakyat dalam negara demokrasi menjadi titik sentral karena pada hakikatnya demokrasi adalah pemerintahan yang dilaksanakan dari, oleh dan untuk rakyat.

Sistem pemerintahan Indonesia menerapkan sistem demokrasi dalam menjalankan pemerintahannya. Demokrasi merupakan bentuk pemerintahan di mana hak untuk membuat keputusan-keputusan politik diselenggarakan oleh warga negara melalui wakil-wakil yang dipilih oleh rakyat dan yang bertanggung jawab kepada rakyat melalui suatu proses pemilihan yang bebas. Maknanya adalah demokrasi merupakan suatu sistem yang meletakan kekuasaan atas rakyat melalui perwakilan yang ada diparlemen yang dipilih secara langsung dalam suatu pemilihan umum. ${ }^{2}$

Upaya yang dilakukan untuk menciptakan pemilu yang berkualitas adalah menciptakan integritas dan profesionalitas penyelenggara pemilu. Komitmen menyelenggarakan pemilu berintegritas yang telah dibangun secara nasional tidak boleh terciderai oleh adanya kepentingan individu dan kepentingan sesaat dari oknum penyelenggara. Setiap pelanggaran yang dilakukan oleh penyelenggara meski masuk dalam kategori pelanggaran ringan, tetap harus dikenai sanksi. Hal ini penting untuk memberikan

\footnotetext{
${ }^{1}$ Hikam, Muhammad A.S. (2002). Politik Kewarganegaraan, Landasan Redemokratisasi di Indonesia. Jakarta: Penerbit Bentara, p. 7.

${ }^{2}$ Rahman, Arifin. (2006). Sistem Politik Indonesia. Surabaya: SIC, p. 21.
} 
peringatan kepada setiap penyelenggara bahwa Komisi Pemilihan Umum (KPU) secara berjenjang tetap melakukan monitoring dan evaluasi terhadap kinerja penyelenggara. Integritas dan profesionalitas mutlak dimiliki semua jajaran penyelenggara pemilu. Penyelenggara harus memiliki daya tahan terhadap setiap godaan yang datang dari luar, termasuk godaan yang datang dari para kandidat yang ikut berkontestasi dalam pemilu. Pelaksanaan supervisi secara berjenjang harus ditingkatkan untuk memastikan kinerja penyelenggara di kabupaten/kota, kecamatan, desa/kelurahan dan Tempat Pemungutan Suara (TPS) sesuai dengan Standar Operasional Prosedur (SOP) yang ditetapkan.

Penyelenggaraan Pemilu Legislatif yang baik harus dapat bekerja sesuai dengan peraturan perundangan yang berlaku seperti yang tercantum dalam Undang-Undang Nomor 8 Tahun 2012 tentang Pemilihan Umum Anggota Dewan Perwakilan Rakyat, Dewan Perwakilan Daerah, dan Dewan Perwakilan Rakyat Daerah, bahwa azas penyelenggara Pemilu yang harus dijadikan pedoman bagi setiap penyelenggara Pemilu, yaitu mandiri, jujur, adil, kepastian hukum, tertib penyelenggara Pemilu, kepentingan umum, keterbukaan, proporsionalitas, profesionalitas, akuntabilitas, efisiensi dan efektivitas. Pemilu yang jujur dan adil membutuhkan peraturan perundangundangan Pemilu beserta aparat yang bertugas menegakkan peraturan perundang-undangan Pemilu tersebut.

Penyelenggara Pemilu seharusnya dilaksanakan dengan langsung, umum, bebas, rahasia (LUBER) serta jujur dan adil (JURDIL), tetapi pada kenyataannya ada penyelenggara pemilu yang justru melakukan tindak pidana pemilu. Salah satunya dalam Putusan Nomor: 70/Pid/2014/PT. Tjk, dengan terdakwa para ketua dan anggota PPK Kecamatan Tulang Bawang Udik, Tumijajar Kabupaten dan Tulang Bawang Tengah Kabupaten Tulang Bawang Barat yang melakukan tindak pidana pemilu yaitu dengan sengaja melakukan penambahan suara pada peserta pemilu tertentu, sebagaimana dimaksud dalam Pasal 309 dan Pasal 287 Undang-Undang Nomor 8 Tahun 2012 tentang Pemilihan Umum Anggota Dewan Perwakilan Rakyat, Dewan Perwakilan Daerah, dan Dewan Perwakilan Rakyat Daerah.

Para terdakwa dalam perkara ini adalah Marzuki Bin Burhanudin, Pahmi Manan Bin Herman Manan, Roni Irawan Bin Nasrullah, Alki Hasan Bin Hasan, Sukri Bin Ali Hasan (Tulang Bawang Udik), Lukmansyah Bin M. Ilyas, Musarif Bin Kasmin, Harwidi Bin Ahmad Muhadi, Tria Albaet Nur Ade Bin Ahuani, Ahmad Setiawan Bin Indra Hidayatullah, Suwandi Bin Hi. Lukman (Tumijajar), Susilo Bin Sudiyono, Rohyanto Bin Abdul Mu'in dan Deswanto Bin Samri Latif (Tulang Bawang Tengah).

Para terdakwa terbukti secara sah dan meyakinkan bersalah melakukan tindak pidana "dengan sengaja melakukan penambahan suara kepada Peserta Pemilu tertentu";- 2. Menjatuhkan pidana kepada para 
terdakwa oleh karena itu dengan pidana penjara selama 3 (tiga) bulan, dan denda sebesar Rp500.000,- (lima ratus ribu rupiah) dengan ketentuan apabila denda tersebut tidak dibayar maka diganti dengan pidana kurungan selama 1 (satu) bulan.

Penjatuhan pidana terhadap terdakwa tersebut pada dasarnya merupakan bentuk pertanggungjawaban pidana bagi para terdakwa, sebagai upaya untuk menjamin kepastian hukum, ketertiban dan perlindungan hukum pada era modernisasi dan globalisasi saat ini dapat terlaksana, apabila berbagai dimensi kehidupan hukum selalu menjaga keselarasan, keseimbangan dan keserasian antara moralitas sipil yang didasarkan oleh nilai-nilai aktual di dalam masyarakat beradab. Baik Perundang-undangan maupun putusan hakim masing-masing adalah sumber hukum dalam membentuk norma atau kaidah hukum. Pembaharuan hukum tentu harus berasal dari sumbernya (sumber hukum), karena tidak mungkin ada perubahan ata pembaharuan hukum apabila sumbernya sendiri tidak pernah berubah atau diperbaharui oleh sumber hukum lainnya. ${ }^{3}$

Permasalahan dalam penelitian ini sebagai berikut:

1. Bagaimanakah pertanggungjawaban pidana terhadap pelaku tindak pidana Pemilu Legislatif Tahun 2014?

2. Apakah dasar pertimbangan hukum hakim dalam menjatuhkan pidana terhadap pelaku tindak pidana Pemilu Legislatif Tahun 2014?

Pendekatan penelitian menggunakan pendekatan yuridis normatif dan yuridis empiris. Pengumpulan data dilakukan dengan studi pustaka dan studi lapangan. Analisis data dilakukan secara kualitatif dan selanjutnya diambil simpulan.

\section{B. Pembahasan}

\section{Pertanggungjawaban Pidana terhadap Pelaku Tindak Pidana Pemilu Legislatif Tahun 2014}

Pertanggungjawaban pidana pada dasarnya merupakan implementasi tanggungjawab seseorang untuk menerima setiap risiko atau konsekuensi yuridis yang muncul sebagai akibat tindak pidana yang telah dilakukannya. Pertanggungjawaban pidana ini menuntut adanya kemampuan bertanggungjawab pelaku. Pada prinsipnya pertanggungjawaban pidana ini sama halnya berbicara mengenai kesalahan yang merupakan asas fundamental dalam hukum pidana, yang mendalilkan bahwa tiada pidana tanpa kesalahan.

\footnotetext{
${ }^{3}$ Tumpa, Harifin A. (2015). "Penerapan Konsep Rechtsvinding dan Rechtsschepping oleh Hakim dalam Memutus Suatu Perkara”, Halrev Journal of Law, 1(2): 127.
} 
Sehubungan dengan kemampuan bertanggungjawab di mana setiap orang akan dimintakan pertanggungjawabannya di depan hukum atas apa yang telah dilakukan. Dalam hal ini tidak semua orang dapat menjadi subyek hukum pidana, karena yang hanya dapat menjadi subyek hukum adalah dengan syarat orang tersebut harus cakap dalam melakukan perbuatan hukum dengan pengertian lain mampu membedakan mana yang baik dan yang tidak baik, termasuk dalam tindak pidana pemilu legislatif.

Pada pelaksanaan pemilu legislatif Tahun 2014 terdapat tindak pidana pemilu sebagaimana tertuang dalam Putusan Nomor: 70/Pid/2014/PT. Tjk, dengan terdakwa para ketua dan anggota PPK Kecamatan Tulang Bawang Udik, Tumijajar Kabupaten dan Tulang Bawang Tengah Kabupaten Tulang Bawang Barat yang melakukan tindak pidana pemilu yaitu dengan sengaja melakukan penambahan suara pada peserta pemilu tertentu, sebagaimana dimaksud dalam Pasal 309 dan Pasal 287 Undang-Undang Nomor 8 Tahun 2012 tentang Pemilihan Umum Anggota Dewan Perwakilan Rakyat, Dewan Perwakilan Daerah, dan Dewan Perwakilan Rakyat Daerah.

Para terdakwa dalam perkara ini adalah Marzuki Bin Burhanudin, Pahmi Manan Bin Herman Manan, Roni Irawan Bin Nasrullah, Alki Hasan Bin Hasan, Sukri Bin Ali Hasan (Tulang Bawang Udik), Lukmansyah Bin M. Ilyas, Musarif Bin Kasmin, Harwidi Bin Ahmad Muhadi, Tria Albaet Nur Ade Bin Ahuani, Ahmad Setiawan Bin Indra Hidayatullah, Suwandi Bin Hi. Lukman (Tumijajar), Susilo Bin Sudiyono, Rohyanto Bin Abdul Mu'in dan Deswanto Bin Samri Latif (Tulang Bawang Tengah).

Para terdakwa terbukti secara sah dan meyakinkan bersalah melakukan tindak pidana "dengan sengaja melakukan penambahan suara kepada Peserta Pemilu tertentu";- 2. Menjatuhkan pidana kepada para terdakwa oleh karena itu dengan pidana penjara selama 3 (tiga) bulan, dan denda sebesar Rp500.000,- (lima ratus ribu rupiah) dengan ketentuan apabila denda tersebut tidak dibayar maka diganti dengan pidana kurungan selama 1 (satu) bulan.

Menurut penjelasan F.X. Supriyadi ${ }^{4}$ terdapat beberapa golongan orang yang oleh hukum positif telah dinyatakan tidak cakap atau kurang cakap untuk bertindak sendiri dalam melakukan perbuatan-perbuatan hukum, tetapi mereka harus diwakili dan dibantu orang lain. Mereka yang oleh hukum dinyatakan tidak cakap untuk melakukan sendiri perbuatan hukum ialah orang yang masih di bawah umur atau belum dewasa menurut undangundang, dan orang yang tidak sehat pikirannya (gila). Selain dua kelompok tersebut maka setiap orang dapat/cakap melakukan perbuatan hukum serta dapat dimintakan pertanggungjawabannya.

\footnotetext{
${ }^{4}$ Hasil Wawancara dengan F.X. Supriyadi. Hakim Pengadilan Negeri Tanjung Karang. Sabtu 31 Oktober 2015.
} 
Terdapat hal-hal yang menyebabkan seseorang tidak dapat dipidana, dengan beberapa alasan yaitu:

a. Alasan pembenar, yaitu alasan yang menghapuskan sifat melawan hukumnya perbuatan, sehingga apa yang dilakukan oleh terdakwa lalu menjadi perbuatan yang patut dan benar.

b. Alasan pemaaf, yaitu alasan yang menghapuskan kesalahan terdakwa, perbuatan yang dilakukan oleh terdakwa tetap bersifat melawan hukum jadi merupakan perbuatan pidana, tetapi dia tidak dipidana karena tidak mempunyai kesalahan.

c. Alasan penghapusan penuntutan, disini soalnya bukan ada alasan pembenar maupun alasan pemaaf, jadi tidak ada pikiran mengenai sifat perbuatan, tetapi pemerintah menganggap bahwa atas dasar utilitas/kemanfaatan kepada masyarakat, sebaliknya tidak diadakan penuntutan.

Alasan-alasan penghapus pidana dibagi menjadi (a) Alasan-alasan yang terdapat dalam batin terdakwa, yaitu Pasal 44 KUHP, (b) Alasan-alasan yang di luar batin terdakwa, yaitu Pasal 48, Pasal 49, Pasal 50, Pasal 51 KUHP dan (c) Pertanggungjawaban dalam hukum Pidana. Beberapa ketentuan tertentu yang mengakibatkan seseorang dalam hal tidak dapat dipertanggungjawabkan atas perbuatan pidana yang dilakukan dengan adanya ketentuan penghapusan pidana sebagaimana yang terdapat dalam Pasal 44, Pasal 48, Pasal 49 Ayat (1), Pasal 49 Ayat (2), Pasal 50, Pasal 51 Ayat (1) dan (2).

Proses penegakan hukum terhadap tindak pidana Pemilu Legislatif secara umum dilaksanakan dalam konteks sistem peradilan pidana di Indonesia, yang meliputi proses penyidikan oleh Kepolisian, penuntutan oleh kejaksaaan dan penjatuhan hukuman/putusan hakim oleh Pengadilan Negeri. Penyidikan tindak pidana Pemilu Legislatif dilaksankan Kepolisian, sesuai dengan ketentuan Pasal 1 Ayat (13) Undang-Undang Nomor 2 Tahun 2002 tentang Kepolisian Negara Republik Indonesia, penyidikan adalah serangkaian tindakan penyidik dalam hal dan menurut cara yang diatur dalam undang-undang untuk mencari serta mengumpulkan bukti yang dengan bukti itu membuat terang tentang tindak pidana yang terjadi dan guna menemukan tersangkanya.

Menurut Pasal 1 Ayat (10) Undang-Undang Nomor 2 Tahun 2002 tentang Kepolisian Negara Republik Indonesia, penyidik adalah pejabat Kepolisian Negara Republik Indonesia yang diberi wewenang oleh undangundang untuk melakukan penyidikan. Penyidik Pembantu adalah pejabat Kepolisian yang diangkat oleh Kepala Kepolisian Negara Republik Indonesia berdasarkan syarat kepangkatan dan diberi wewenang tertentu dalam melakukan tugas penyidikan yang diatur dalam undang-undang. 
Penyidikan dilakukan untuk mencari serta mengumpulkan bukti-bukti yang pada tahap pertama harus dapat memberikan keyakinan, walaupun sifatnya masih sementara, kepada penuntut umum tentang apa yang sebenarnya terjadi atau tentang tindak pidana yang telah dilakukan serta siapa tersangkanya. Tujuan penyidikan secara konkrit tindakan penyidikan dapat diperinci sebagai tindakan yang dilakukan oleh penyidik untuk mendapatkan keterangan tentang tindak pidana apa yang dilakukan, kapan tindak pidana dilakukan, dengan apa tindak pidana dilakukan, bagaimana tindak pidana dilakukan, mengapa tindak pidana dilakukan dan siapa pembuatnya atau tindak pidana Pemilu Legislatif.

Penyidikan terhadap tindak pidana Pemilu Legislatif merupakan bagian dari tugas Kepolisian sebagai penegak hukum yang berupaya semaksimal mungkin dalam melakukan berbagai langkah strategis dan konstruktif dalam rangka mewujudkan keamanan dalam negeri yang meliputi terpeliharanya keamanan dan ketertiban masyarakat, tertib dan tegaknya hukum. Penyidikan terhadap tindak pidana Pemilu Legislatif, dilaksanakan setelah menerima laporan dari Panitia Pengawas Pemilu 1 x 24 jam sejak diputuskan dalam rapat pleno pembahasan pada Sentra Gakkumdu guna memperoleh bukti-bukti yang kuat untuk menentukan apakah termasuk sebagai tindak pidana Pemilu Legislatif. Atas dasar laporan tersebut kemudian Kepolisian melakukan tahapan penyidikan selama 14 (empat belas) hari untuk mengungkap tindak pidana Pemilu Legislatif yang berkaitan dengan acara pidana meliputi ketentuan-ketentuan tentang datadata penyidikan, ketentuan-ketentuan tentang diketahuinya terjadinya delik, pemeriksaan di tempat kejadian, pemanggilan tersangka atau terdakwa, penahanan sementara, penggeledahan, pemeriksaan atau investegasi, berita acara (penggeledahan, interogasi, dan pemeriksaan di tempat), penyitaan dan pelimpahan perkara.

Menurut penjelasan Anyk Kurniasih ${ }^{5}$ Penuntutan terhadap tindak pidana Pemilu Legislatif dilaksanakan Kejaksaan. Setelah bukti-bukti dikumpulkan dan yang diduga tersangka telah ditemukan maka penyidik menilai dengan cermat, apakah cukup bukti untuk dilimpahkan kepada Penuntut Umum (kejaksaan) atau ternyata bukan tindak pidana. Jika setelah melalui tahapan penyidikan penyidik berpendapat bahwa peristiwa tersebut merupakan tindak pidana Pemilu Legislatif maka penyidik mengirimkan Surat Pemberitahuan Dimulainya Penyidikan yang dilanjutkan dengan pengiriman berkas perkara oleh penyidik kepada Penuntut Umum untuk dilakukan penelitian dalam waktu 3 (tiga) hari dan apabila berdasarkan hasil penelitian berkas perkara sudah memenuhi persyaratan maka Penuntut

\footnotetext{
${ }^{5}$ Hasil wawancara dengan Anyk Kurniasih selaku Jaksa Penuntut Umum pada Kejaksaan Negeri Bandar Lampung, Rabu 18 Oktober 2015.
} 
Umum segera menerbitkan P-21P (Pemberitahuan berkas perkara pemilu sudah lengkap) dan dalam waktu 5 (lima) hari sejak diserahkannya tersangka dan barang bukti oleh penyidik Penuntut Umum melimpahkan perkara tindak pidana pemilu ke Pengadilan Negeri untuk dilakukan penuntutan. Dan sebaliknya jika penyidik berpendapat bahwa peristiwa tersebut bukan merupakan tindak pidana maka penyidikan dihentikan demi hukum. Pemberhentian penyidikan ini dibertahukan kepada Penuntut Umum dan kepada tersangka atau keluarganya.

Jaksa Penuntut Umum (JPU) pada dasarnya adalah seseorang yang diberi wewenang oleh undang-undang untuk melakukan penuntutan dan pelaksanaan penetapan hakim. Berdasarkan Pasal 33 Undang-Undang Nomor 16 Tahun 2004 tentang Kejaksaan, dalam melaksanakan tugas dan wewenangnya, jaksa membina hubungan kerjasama dengan badan penegak hukum dan keadilan serta badan negara atau instansi lainnya. Kejaksaan dalam melaksanakan kekuasaan negara di bidang penuntutan dilakukan secara merdeka, di mana dalam melaksanakan tugas dan tanggungjawab itu seorang jaksa harus terlepas dari pengaruh kekuasaan pemerintah dan pengaruh kekuasaan lainnya. Hal ini berdasarkan Pasal 2 UU tersebut. Selanjutnya dalam Pasal 37 Ayat (1) disebutkan bahwa Jaksa Agung bertanggungjawab atas penuntutan yang dilaksanakan secara independen demi keadilan berdasarkan hukum dan hati nurani.

Berdasarkan Pasal 1 angka 1 UU Nomor 16 Tahun 2004 tentang Kejaksaan Republik Indonesia jaksa adalah pejabat fungsional yang diberi wewenang oleh undang-undang untuk bertindak sebagai penuntut umum dan pelaksana putusan Pengadilan yang telah memperoleh kekuatan hukum tetap serta wewenang lain berdasarkan undang-undang. Tugas dan kewenangan jaksa dalam bidang pidana diatur dalam Pasal 30 Ayat (1) UU Kejaksaan antara lain:

(1) Melakukan penuntutan;

(2) Melaksanakan penetapan hakim dan putusan Pengadilan yang telah memperoleh kekuatan hukum tetap;

(3) Melakukan pengawasan terhadap pelaksanaan putusan pidana bersyarat, putusan pidana pengawasan, dan keputusan lepas bersyarat

(4) Melakukan penyidikan terhadap tindak pidana berdasarkan undang-undang

(5) Melengkapi berkas perkara tertentu dan untuk itu dapat melakukan pemeriksaan tambahan sebelum dilimpahkan ke Pengadilan yang dalam pelaksanaannya dikoordinasikan dengan penyidik.

Semua tindakan yang dilakukan oleh Jaksa Penuntut Umum baik dalam proses pra penuntutan maupun penuntutan sesungguhnya dilakukan 
atas dasar keadilan dan kebenaran berdasarkan Ketuhanan Yang Maha Esa. Penegakan hukum demi keadilan juga mencakup adil bagi terdakwa, adil bagi masyarakat yang terkena dampak akibat perbuatan para terdakwa dan adil di mata hukum, dengan begitu dengan sendirinya apa yang dilakukan oleh Jaksa Penuntut Umum dalam rangka penegakan hukum adalah untuk mencapai tujuan hukum yakni kepastian hukum, menjembatani rasa keadilan dan kemanfaatan hukum bagi para pencari keadilan.

Tahapan selanjutnya adalah penjatuhan vonis oleh Hakim Pengadilan Terhadap Tindak pidana Pemilu Legislatif dalam rangka penegakan hukum. Sistem peradilan pidana sebagai suatu jaringan peradilan yang menggunakan hukum pidana sebagai sarana utamanya, baik hukum pidana materil, hukum pidana formil maupun hukum pelaksanaan pidana. Namun demikian kelembagaan substansial ini harus dilihat dalam kerangka atau konteks sosial. Sifatnya yang terlalu formal apabila dilandasi hanya untuk kepentingan kepastian hukum saja akan membawa bencana berupa ketidakadilan. Dengan demikian demi apa yang dikatakan sebagai precise justice, maka ukuran-ukuran yang bersifat materil, yang nyata-nyata dilandasi oleh asas-asas keadilan yang bersifat umum benar-benar harus diperhatikan dalam penegakan hukum. Sistem peradilan pidana pelaksanaan dan penyelenggaan penegakan hukum pidana melibatkan badan-badan yang masing-masing memiliki fungsi sendiri-sendiri. Badan-badan tersebut yaitu Kepolisian, Kejaksaan, Pengadilan dan lembaga pemasyarakatan. Dalam kerangka kerja sitematik ini tindakan badan yang satu akan berpengaruh pada badan yang lainnya.

Mekanisme penegakan hukum pidana Pemilu haruslah memenuhi prinsip demokrasi, maka setiap putusan hakim harus selalu memenuhi paling tidak 3 (tiga) perspektif penting di antaranya: perpektif hukum pidana materi, perspektif hukum pidana formil dan perspektif pelaksanaan pemidanaan. ${ }^{6}$

Pertama, perspektif pidana materil berisikan tingkah laku yang diancam dengan pidana, siapa yang dapat dipidana dan berbagai macam pidana yang dapat dijatuhkan. Dengan perkataan lain hukum pidana materil berisikan norma dan sanksi hukum pidana serta ketentuan-ketentuan umum yang membatasi, memperluas atau menjelaskan norma dan pidana tersebut.

Kedua, perspektif pidana formil (hukum pidana ajektif) atau lazim pula disebut dengan hukum acara pidana, yang bisa diartikan seluruh peraturan yang memuat cara-cara Negara dalam menggunakan haknya untuk melaksanakan penegakan hukum pidana yang berimplikasi terhadap penerapan sanksi bagi para pelanggar hukum pidana materil.

\footnotetext{
${ }^{6}$ Mulyadi, Dedi. (2013), Perbandingan Tindak Pidana Pemilu Legislatif - dalam perspektif hukum di Indonesia, Cetakan Kesatu. Bandung: PT Refika Aditama, p. 276.
} 
Ketiga, perspektif pelaksanaan pidana atau pemidanaan tidak dapat dipisahkan dari sistem peradilan pidana (criminal justice system). Pasal 270 KUHAP mengatur bahwa Jaksa yang melaksanakan putusan pengadilan. Bagaimana caranya jaksa melaksanakan keputusan tersebut diatur dalam peraturan pelaksanaan KUHAP atau dengan kata lain Jaksa yang tidak menjadi Penuntut Umum untuk suatu perkara boleh melaksanakan Putusan Pengadilan.

Menurut penjelasan Nurrahman Yusuf $^{7}$ pada dasarnya penegakan hukum Pemilu memerlukan pembagian tindak pidana Pemilu dibagi dalam 2 (dua) kategori yaitu tindak pidana pelanggaran dan tindak pidana kejahatan. Dengan mekanisme hukum acara yang juga acara pemeriksaan singkat dan acara pemeriksaan biasa. Khusus untuk tindak pidana Pemilu maka peradilannya permanen yang berada di tingkat Pengadilan Tinggi dengan keputusan yang berisifat final and binding. Selain itu jaksanya adalah jaksa khusus yang ditempatkan di pengawas Pemilu yang tugasnya melakukan penuntutan langsung terhadap hasil penyidikan Polisi khusus Pemilu yang juga ditempatkan di pengawas Pemilu.

Upaya untuk mencapai efektivitas penyelidikan dan penyidikan perkara tindak pidana Pemilu, sebaiknya dibentuk unit khusus polisi yang dilatih menangani tindak pidana Pemilu. Sebab, penanganan tindak pidana Pemilu, selain membutuhkan pengetahuan umum mengenai tindak pidana, juga perlu pengetahuan khusus karena Pemilu merupakan proses politik di mana berbagai modus tindak pidana Pemilu sangat tersamar atau sangat rumit, misalnya politik uang yang dilakukan dengan modus sumbangan, santunan, hadiah lomba, potongan harga, kenaikan gaji, atau kecurangan dalam melaporkan perolehan dana kampanye. Diharapkan juga dibentuk unit khusus jaksa yang menangani perkara pidana Pemilu. Pertimbangannya, sebagaimana dalam proses penyidikan, jaksa untuk perkara pidana Pemilu juga perlu pembekalan pengetahuan seputar Pemilu.

Perkara tindak pidana Pemilu bermuara di Pengadilan yang akan menyelesaikan perkara tersebut sesuai waktu yang ditentukan. Di sini juga diharapkan ada hakim khusus yang menangani tindak pidana Pemilu karena dalam memberikan pertimbangan dan putusan menyangkut tindak pidana Pemilu dibutuhkan pengetahuan yang luas mengenai hukum dan proses Pemilu. Jauh-jauh hari diharapakan hakim sudah mempelajari hukum dan proses Pemilu serta kasus-kasus tindak pidana Pemilu yang pernah ada sebelumnya.

Seluruh komponen dalam sistem ini selain menguasai pengetahuan dan skill hukum pada umumnya mesti menguasai hukum dan proses Pemilu,

7 Hasil wawancara dengan Nurrahman Yusuf selaku Anggota Panwaslu Kota Bandar Lampung. Senin 9 November 2015. 
dengan demikian komponen yang bekerja dalam sistem peradilan pidana khusus untuk menangani tindak pidana Pemilu ini adalah: pertama, polisi (yakni tim khusus yang menangani tindak pidana pemilu); kedua, jaksa (yakni tim khusus yang menangani tindak pidana pemilu; dan ketiga, Pengadilan (yakni hakim-hakim khusus yang menangani tindak pidana pemilu). Dengan adanya polisi khusus Pemilu dan Jaksa khusus Pemilu yang ditempatkan oleh kedua instansi tersebut pada lembaga pengawas Pemilu maka penyelidikan, penyidikan maupun penuntutan langsung dilakukan oleh badan pengawas Pemilu tanpa harus berkordinasi dengan Kepolisian maupun Kejaksaan, sehingga penyelesaian kasus lebih efektif dan optimal.

Menurut penjelasan Nurrahman Yusuf $^{8}$ berkaitan dengan penegakan hukum dalam pelanggaran administrasi, maka ke depan perlu dipikirkan dengan memberikan ruang yang besar terhadap penguatan kelembagaan dan kewenangan Pengawas Pemilu, dengan demikian maka diharapkan peran Pengawas Pemilu menjadi wasit yang dapat diandalkan khususnya dalam menyelesaikan berbagai permasalahan pemilu melalui optimalisasi pelaksanaan kewenangan yang bertanggungjawab dan mampu membangun sinergitas antar lembaga Pemilu yang ada, serta menghindari arogansi internal organisasi yang dapat menimbulkan konflik antar lembaga Pemilu.

Pertanggungjawaban pidana pemilu legislatif dapat dilihat dari bentuk kesalahan yaitu kesengajaan (dolus) dan kealpaan/lalai (culpa), di luar dari dua bentuk kesalahan ini yang merupakan hubungan batin dari pelaku dan perbuatannya, KUHP tidak mengenal macam kesalahan lain. Adapun sikap batin yang berkaitan dengan perbuatan yang menimbulkan celaan sebagai berikut:

\section{a. Kesengajaan (dolus)}

Sengaja merupakan perbuatan yang dikehendaki dan diketahui. Hal ini berarti seseorang yang berbuat sengaja itu harus dikehendaki apa yang diperbuat dan harus diketahui juga atas apa yang diperbuat. Sengaja sebagaimana dimaksud adalah bentuk sengaja yang paling sedehana, sengaja adalah yang menyatakan sengaja sebagai maksud apabila pembuat menghendaki akibat perbuatanya, ia tidak pernah melakukan perbuatannya apabila pembuat mengetahui bahwa akibat perbuatannya tidak akan terjadi.

Sengaja dengan kesadaran tentang kepastian. Sengaja dengan kesadaran kepastian adalah pembuat yakin bahwa akibat yang dimaksudkannya tidak akan dicapai tanpa terjadinya akibat yang tidak dimaksud, atau menurut teori kehendak, apabila pembuat juga menghendaki akibat atau hal-hal yang turut serta mempengaruhi terjadinya akibat yang

8 Hasil wawancara dengan Nurrahman Yusuf selaku Anggota Panwaslu Kota Bandar Lampung. Senin 9 November 2015. 
lebih dahulu telah dapat digambarkan sebagai suatu akibat yang tidak dapat dielakkan terjadinya, maka orang itu melakukan sengaja dengan kepastian terjadi.

Sengaja dengan kesadaran kemungkinan sekali terjadi/sengaja bersyarat/dolus evantualis, adalah terjadi jika pembuat tetap melakukan yang dikehendakinya walaupun ada kemungkinan akibat lain yang sama sekali tidak diinginkannya terjadi, jika walaupun akibat (yang sama sekali tidak diinginkan) itu diinginkan dari pada menghentikan perbuatannya, maka terjadi pula kesengajaan. Untuk adanya kesengajaan diperlukan dua syarat: (1) Terdakwa mengetahui kemungkinan adanya akibat/keadaan yang merupakan delik, dibuktikan dari kecerdasan pikirannya yang dapat disimpulkan antara lain dari pengalaman, pendidikan/lapisan masyarakat di mana terdakwa hidup (2) Sikapnya terhadap kemungkinan itu andaikata timbul, dapat disetujui atau berani menanggung resikonya, dapat dibuktikan dari ucapan-ucapan terdakwa di sekitar perbuatan, tidak mengadakan usaha untuk mencegah akibat yang tidak diinginkan. Berdasarkan penjelasan di atas apabila seorang pelaku pemilu legislatif mengetahui bahwa perbuatannya bersifat melanggar hukum dan dengan sengaja melakukan tindak pidana pemilu legislatif maka ia harus mempertanggung jawabkan perbuatan tersebut di depan hukum.

\section{b. Kelalaian/kealpaan (culpa)}

Kelalaian (culpa) terletak antar sengaja dan kebetulan, bagaimanapun juga culpa dipandang lebih ringan dibanding dengan sengaja, oleh karena itu delik culpa, culpa itu merupakan delik semu (quasidelict) sehingga diadakan pengurangan pidana. Culpa mencakup (cermat) berpikir, kurang pengetahuan atau kurang terarah, dan ihwal culpa disini jelas merujuk kepada kemampuan psikis seseorang dan karena itu dapat dikatakan bahwa culpa berari tidak atau kurang menduga secara nyata (terlebih dahulu kemungkinan munculnya) akibat fatal dari tindakan orang tersebut padahal itu mudah dilakukan dan karena itu seharusnya dilakukan.

Culpa tidak hanya muncul sebagai elemen kesalahan dalam delikdelik omisi, tapi juga dalam delik-delik (komisi) biasa lainnya, kadang kala dalam ketentuan Pasal 359 dan 360 KUHP, soal perbuatan tidak disinggung, sehingga mengimplikasikan bahwa beragam tindakan tercakup di dalamnya, Kesamaannya dengan delik omisi sekalipun hanya dalam hubungan kondisi fisik dengan tindakan, adalah bahwa keduanya menyangkut tindakan membiarkan (tidak berbuat). Juga dalam hal culpa untuk delik (komisi) biasa, kemampuan psikis seseorang tidak digunakan, padahal kemampuan tersebut seharunya digunakan. 
Delik culpa mengandung dua macam, yaitu delik kelalaian yang menimbulkan akibat dan yang tidak menimbulkan akibat, tapi yang diancam pidana ialah perbuatan ketidak hati-hatian itu sendiri, perbedaan keduanya mudah dipahami yaitu kelalaian yang menimbulkan akibat dengan terjadinya akibat itu maka diciptalah delik kelalaian, sedangkan bagi yang tidak perlu menimbulkan akibat dengan kelalaian/kurang kehati-hatian itu sendiri sudah diancam dengan pidana.

Syarat-syarat elemen yang harus ada dalam delik kealpaan yaitu (1) Tidak mengadakan praduga-praduga sebagaimana diharuskan oleh hukum, adapun hal ini menunjuk kepada terdakwa berpikir bahwa akibat tidak akan terjadi karena perbuatannya, padahal pandangan itu kemudian tidak benar. Kekeliruan terletak pada salah pikir/pandang yang seharusnya disingkirkan. Terdakwa sama sekali tidak punya pikiran bahwa akibat yang dilarang mungkin timbul karena perbuatannya. Kekeliruan terletak pada tidak mempunyai pikiran sama sekali bahwa akibat mungkin akan timbul hal mana sikap berbahaya. (2) Tidak mengadakan penghati-hatian sebagaimana diharuskan oleh hukum, mengenai hal ini menunjuk pada tidak mengadakan penelitian kebijaksanaan, kemahiran/usaha pencegah yang ternyata dalam keadaan yang tertentu/dalam caranya melakukan perbuatan.

Upaya pembenahan pengawas Pemilu maka Lembaga pengawas Pemilu memiliki peran dan posisi yang strategis. Keberadaan pengawas ini bukan sekedar pelengkap dari kebutuhan kelembagaan penyelenggaraan Pemilu, namun lembaga pengawas Pemilu haruslah diposisikan sebagai pengemban tanggung jawab atas semua proses dan hasil Pemilu, sehingga fungsi pengawasan pada akhirnya akan efektif dan efisien. Pengawas Pemilu dibentuk dengan harapan agar pelaksanaan tahapan-tahapan Pemilu berjalan sesuai dengan peraturan dan jadwal. Fungsi pengawasan mestinya melekat atau berjalan seiring pengawas Pemilu beriring artinya penanganan pelanggaran administrasi diserahkan ke pengawas Pemilu untuk menanganinya dan berhak menjatuhkan sanksi administrasi demikian juga terhadap penanganan pelanggaran tindak pidana Pemilu ditangani oleh polisi maupun jaksa yang dipersiapkan untuk itu yang berada di kantor pengawas Pemilu.

Laporan pelanggaran penyelenggaraan Pemilu diatur dalam UndangUndang Nomor 12 Tahun 2008 Bab XX. Secara umum, pelanggaran diselesaikan melalui Bawaslu/Panwaslu sebagai lembaga yang memiliki kewenangan melakukan pengawasan terhadap setiap tahapan pelaksanaan Pemilu. Dalam proses pengawasan tersebut, Bawaslu dapat menerima laporan, melakukan kajian atas laporan dan temuan adanya dugaan pelanggaran, dan meneruskan temuan dan laporan dimaksud kepada institusi yang berwenang. Selain berdasarkan temuan Bawaslu, pelanggaran dapat dilaporkan oleh anggota masyarakat yang mempunyai hak pilih, pemantau 
Pemilu dan peserta Pemilu kepada Bawaslu, Panwaslu Propinsi, Panwaslu Kabupaten/Kota paling lambat 7 (tujuh) hari sejak terjadinya pelanggaran Pemilu. Bawaslu memiliki waktu selama 3 (tiga) hari untuk melakukan kajian atas laporan atau temuan terjadinya pelanggaran.

Apabila Bawaslu menganggap laporan belum cukup lengkap dan memerlukan informasi tambahan, maka Bawaslu dapat meminta keterangan kepada pelapor dengan perpanjangan waktu selama 5 (lima) hari. Berdasarkan kajian tersebut, Bawaslu dapat mengambil kesimpulan apakah temuan dan laporan merupakan tindak pelanggaran Pemilu atau bukan. Dalam hal laporan atau temuan tersebut dianggap sebagai pelanggaran, maka Bawaslu membedakannya menjadi pelanggaran Pemilu yang bersifat administratif dan pelanggaran yang mengandung unsur pidana, kemudian meneruskannya kepada instansi yang berwenang.

Menurut penjelasan Ahmad Fauzan ${ }^{9}$ pelanggaran Pemilu yang bersifat administrasi menjadi kewenangan KPU untuk menyelesaikannya. Sesuai dengan sifatnya, maka sanksi terhadap pelanggaran administrasi adalah sanksi administrasi. Khusus terkait dengan pelanggaran yang dilakukan oleh penyelenggara maka KPU dapat menggunakan Peraturan KPU tentang Kode Etik KPU. Aturan lebih lanjut tentang tata cara penyelesaian pelanggaran administrasi dibuat dalam peraturan KPU. Meski pelanggaran administrasi menjadi kompetensi KPU untuk menyelesaikannya, tetapi UU Pemilu juga memberikan wewenang tersebut kepada Panwaslu Kabupaten/Kota sebagaimana dapat dibaca pada Pasal 249, dan selanjutnya disampaikan kepada KPU, KPU Provinsi, atau KPU Kabupaten/Kota berdasarkan Pasal 250 Ayat (1) huruf $b$.

Menurut penjelasan Budiono ${ }^{10}$ adanya pengelembungan suara dalam pelaksanaan Pemilu DPR, DPD dan DPRD Tahun 2014 menunjukkan Pemilu yang kurang baik, sebab dengan mekanisme peraturan yang telah dirancang dengan sebaik-baiknya namun dalam pelaksanaannya banyak sekali kecurangan. Sanksi pidana dalam penegakan hukum pemilu perlu diperberat sehingga dapat menimbulkan efek jera dan dapat meningkatkan ketelitian dan kehati-hatian dari petugas pemilu. Hal ini karena dalam Pemilihan Umum ini masyarakat menentukan nasib bangsanya di mana menentukan siapa pemimpinya, karena kecurangan ini akan berimbas pada nasib negara dan mencedrai pesta rakyat yang harus dilaksanakan luber dan jurdil.

\footnotetext{
${ }^{9}$ Hasil wawancara dengan Ahmad Fauzan, Anggota KPU Provinsi Lampung. Kamis 5 November 2015.

${ }^{10}$ Hasil wawancara dengan Budiono, Akademisi Fakultas Hukum Unila. Sabtu 7 November 2015.
} 
Mengacu kepada pasal UU Pemilu, maka temuan dan laporan adanya dugaan pelanggaran Pemilu yang mengandung unsur pidana diteruskan oleh Bawaslu kepada Penyidik untuk selanjutnya diproses melalui Pengadilan dalam yuridiksi peradilan umum yang ditangani oleh hakim khusus. Pengaturan lebih jauh mengenai hakim khusus tersebut akan diatur melalui Peraturan MA, kecuali yang diatur secara berbeda dalam UU Pemilu, maka hakim dalam memeriksa, mengadili dan memutus perkara pidana Pemilu menggunakan KUHAP sebagai pedoman beracara.

Menurut penjelasan Anyk Kurniasih ${ }^{11}$ berdasarkan hasil kajian Bawaslu yang didukung dengan data permulaan yang cukup, pelanggaran yang mengandung unsur pidana dilanjutkan kepada penyidik untuk diselesaikan melalui peradilan umum dan dalam jangka waktu 14 hari setelah laporan dari Bawaslu, penyidik harus menyampaikan hasil penyidikan beserta berkas perkara kepada Penuntut Umum (PU). Jika hasil penyidikan dianggap belum lengkap, maka dalam waktu paling lama 3 hari Penuntut Umum mengembalikan berkas perkara kepada penyidik Kepolisian disertai dengan petunjuk untuk melengkapi berkas bersangkutan. Perbaikan berkas oleh penyidik maksimal 3 hari untuk kemudian dikembalikan kepada PU. Maksimal 5 hari sejak berkas diterima, PU melimpahkan berkas perkara kepada pengadilan.

Tujuh hari sejak berkas perkara diterima Pengadilan Negeri memeriksa, mengadili, dan memutus perkara pidana Pemilu. Kepada pihak yang tidak menerima putusan PN tersebut memiliki kesempatan banding ke Pengadilan Tinggi. Permohonan banding terhadap putusan tersebut diajukan paling lama 3 hari setelah putusan dibacakan. PN melimpahkan berkas perkara permohonan banding kepada PT paling lama 3 hari sejak permohonan banding diterima.

PT memiliki kesempatan untuk memeriksa dan memutus permohonan banding sebagaimana dimaksud paling lama 7 hari setelah permohonan banding diterima. Putusan banding tersebut merupakan putusan yang bersifat final dan mengikat sehingga tidak dapat diajukan upaya hukum lain. Tiga hari setelah putusan Pengadilan dibacakan, PN/PT harus telah menyampaikan putusan tersebut kepada PU. Putusan sebagaimana dimaksud harus dilaksanakan paling lambat 3 hari setelah putusan diterima jaksa. Jika perkara pelanggaran pidana Pemilu menurut UU Pemilu dipandang dapat mempengaruhi perolehan suara peserta Pemilu maka putusan Pengadilan atas perkara tersebut harus sudah selesai paling lama 5 hari sebelum KPU menetapkan hasil Pemilu secara nasional. Khusus terhadap putusan yang berpengaruh terhadap perolehan suara ini, KPU, KPU Propinsi dan KPU

${ }^{11}$ Hasil wawancara dengan Anyk Kurniasih selaku Jaksa Penuntut Umum pada Kejaksaan Negeri Bandar Lampung, Rabu 18 Oktober 2015. 
Kabupaten/Kota dan peserta harus sudah menerima salinan putusan Pengadilan pada hari putusan dibacakan. KPU berkewajiban untuk menindaklanjuti putusan sebagaimana dimaksud.

Menurut penjelasan Budiono, siapapun yang melakukan kecurangan dalam pemilu harus ditindak, terlebih apabila itu petugasnya sendiri yang diamanatkan untuk menjunjung tinggi asas luber dan jurdil. PPK dan Komisionernya harus dikenakan sanksi. Harapan saya kedepannya bukan hanya para petugasnya yang terkena sanksi apabila terbukti melakukan kecurangan, tetapi pihak yang diuntukan dari kecurangan tersebut harus dikenakan sanksi juga. ${ }^{12}$

Peran Badan Pengawas Pemilu (Bawaslu) sebagai sebuah lembaga pengawas Pemilu yang bersifat permanen (tetap) dan jajaran di bawahnya Panitia Pengawas Pemilu (Panwaslu) baik di tingkat Kabupaten/Kota, Kecamatan maupun Pengawas Pemilu Lapangan (PPL) di tingkat Kelurahan yang bersifat ad hoc (sementara) dalam penanganan dugaan pelanggaran tindak pidana Pemilu merupakan pintu masuk pada sistem penegakan hukum Pemilu yang melibatkan Kepolisian dan Kejaksaan. Dalam posisi demikian, lembaga pengawas Pemilu (Bawaslu/Panwaslu) seringkali mengalami kendala dengan keterbatasan waktu dalam penanganan dugaan pelanggaran pidana Pemilu, tidak ada kewenangan untuk menyita alat bukti dan juga tidak ada kewenangan untuk mewajibkan saksi memberi keterangan.

Kejaksaan pada Pemilu 2014, merespon kondisi dengan Kepolisian dan Panwaslu membentuk Sentra penegakan Hukum terpadu (Sentra Gakkumdu) untuk mengefektifkan koordinasi antara institusi yang terlibat dalam penanganan pelanggaran pidana Pemilu. Nota kesepakatan bersama Badan Pengawas Pemilihan Umum RI, Kepolisian Negara RI dan Kejaksaan RI Nomor Kep-005/A/JA/01/2013 tentang Sentra Penegakan Hukum Terpadu:

1) Sebagai forum koordinasi antar pihak dalam proses tindak pidana Pemilu;

2) Pelaksanaan pola tindak pidana Pemilu;

3) Sebagai pusat data dan informasi tentang tindak pidana Pemilu;

4) Pertukaran data dan/atau informasi;

5) Peningkatan kompetensi dalam penanganan dugaan tindak pidana Pemilu;

6) Pelaksanaan monitoring dan evaluasi tindak lanjut penanganan tindak pidana Pemilu.

Nota kesekapatan tersebut memuat pembentukan Sentra Gakkumdu pada tingkat pusat, provinsi dan kabupaten/kota, yang mana menunjuk Koordinator Divisi Hukum dan Penindakan Pelanggaran pada Bawaslu;

${ }^{12}$ Hasil wawancara dengan Budiono, Akademisi Fakultas Hukum Unila. Sabtu 7 November 2015. 
Kabareskrim Polri dan Jampidum Kejagung sebagai Ketua dalam struktur keanggotaan Sentra Gakkumdu di tingkat pusat, sedangkan Ketua Bawaslu, Kapolri dan Jaksa Agung sebagai Pembina Sentra Gakkumdu di tingkat pusat.

Sesuai Nota Kesepakatan, fungsi Sentra Gakkumdu adalah sebagai forum koordinasi dalam proses penanganan pelanggaran tindak pidana Pemilu, pelaksanaan pola tindak pidana Pemilu itu sendiri, pusat data, peningkatan kompetensi, monitoring-evaluasi. Sementara mengenai pola penanganan tidak pidana Pemilu telah dirinci dalam Standar Operasional dan Prosedur (SOP) tentang Polda Tindak Pidana Pemilu pada Sentra Gakkumdu.

Menurut SOP Sentra Gakkumdu, penanganan tindak pidana Pemilu dilaksanakan melalui 3 (tiga) tahap yaitu: a) Penerimaan, pengkajian dan penyampaian laporan/temuan dugaan tindak pidana Pemilu kepada Pengawas Pemilu; Pengawas Pemilu berwenang menerima laporan/temuan dugaan pelanggaran Pemilu yang diduga mengandung unsur tindak pidana Pemilu, dengan menuangkan dalam Formulir Pengaduan. Setelah menerima laporan/temuan adanya dugaan tindak pidana Pemilu, Pengawas Pemilu segera berkoordinasi dengan Sentra Gakkumdu dan menyampaikan laporan/temuan tersebut kepada Sentra Gakkumdu dalam jangka waktu paling lama 24 Jam sejak diterimanya laporan/temuan. b) Tindak lanjut Sentra Gakkumdu terhadap laporan/temuan dugaan tindak pidana pemilu; dalam tahap ini dilakukan pembahasan oleh Sentra Gakkumdu dengan dipimpin oleh anggota Sentra Gakkumdu yang berasal dari unsur Pengawas Pemilu. Peserta Rapat membahas dan memberikan saran dan pendapat terhadap syarat formil dan materil, pasal yang diterapkan dan pemenuhan unsur tindak pidana Pemilu. c) Tindak lanjut Pengawas Pemilu terhadap rekomendasi Sentra Gakkumdu, dalam tahap ini disusun rekomendasi Sentra Gakkumdu, yang menentukan apakah suatu laporan/temuan merupakan dugaan tindak pidana Pemilu atau bukan, atau apakah laporan/temuan tersebut perlu dilengkapi dengan syarat formil/syarat materil.

Mekanisme penanganan dengan sinergi antar lembaga demikian ini diharapkan dapat secara efektif dan efisien menjawab berbagai kendala penanganan tindak pidana Pemilu yang selama ini dikhawatirkan terjadi. terutama kekhawatiran tentang ketidaksepahaman penerapan peraturan antara pengawas Pemilu dengan Kepolisian dan Kejaksaan.

Koordinasi penanganan perkara pidana Pemilu di antara institusi penegak hukum sangat diperlukan mengingat adanya limitasi dalam penanganan perkara pidana Pemilu selain itu juga harus diperhatikan bahwa kadangkala pelanggaran pidana Pemilu melibatkan tokoh-tokoh masyarakat sehingga penanganannya harus dilakukan secara hati-hati agar tidak terjadi gejolak di masyarakat. Dalam penanganan perkara pidana, jaksa memiliki 
tanggungjawab dalam hal beban pembuktian dalam persidangan nanti. Sehingga di lapangan, jaksa yang paling berkepentingan dalam kelengkapan formil dan materil dalam perkara tindak pidana termasuk pidana Pemilu. Mengingat tanggungjawab di atas maka salah satu cara menjalankan tanggungjawabnya tersebut maka gelar perkara di forum Gakkumdu manakala Panwaslu menyampaikan peristiwa yang menurut Panwaslu adalah pelanggaran pidana Pemilu, maka jaksa akan memberikan supervisi tentang syarat yang diperlukan agar sebuah perkara berhasil dalam penuntutan di persidangan.

Menurut Maroni, diperlukan pembaharuan mengenai jumlah dan lama sanksi pidana dan sanksi dendanya dalam peraturan pemilu, mengingat dalam setiap pelaksanaan pemilu saat-saat ini kecurangan-kecurangan itu selalu terjadi dan dirasa perlu sanksi yang lebih tegas lagi untuk menekan angka kecurangan-kecurangan yang terjadi, karena tindak pidana pemilu ini bukan tindak pidana biasa. Harapannya ke depan, tindak pidana pemilu ini masuk dalam kejahatan khusus, yang ke depan politik hukum pidana merancang bahwa tindak pidana pemilu ini masuk ke dalam kejahatan politik. Mengingat tindak pidana pemilu ini bukan hal yang sepele, karena efek kecurangan ini akan berimbas pada nasib negara dan mencedrai pesta rakyat yang harus dilaksanakan luber dan jurdil. ${ }^{13}$

Menurut penjelasan Maroni, terkait dengan pidana penjara 3 bulan yang dijatuhkan dalam Perkara Pemilu DPR, DPD, dan DPRD di Tulang Bawang Barat, sanksi pidana sebenarnya tidak boleh hanya berfikiran harus menimbulkan kesengsaraan bagi pelakunya dan dapat menimbulkan efek jera. Karena kita juga harus melihat dari segi kemanfaatannya. Dalam perkara ini para petugas melakukan kecurangan dalam keadaan sadar, tentunya sanksi pidananya di sesuaikan dengan perbuatannya. Peraturan sanksi tindak pidana pemilu ini, sanksi pidananya tergolong rendah dan begitu juga sanksi denda. ${ }^{14}$

Ketentuan mengenai pemidanaan ini juga memberikan kesempatan untuk melakukan perubahan atau penyesuaian pidana kepada narapidana. Pelaku yang dijatuhi pidana atau tindakan yang telah berkekuatan hukum tetap dapat dilakukan perubahan atau penyesuaian dengan mengingat perkembangan narapidana dan tujuan pemidanaan.

Sanksi pidana yang diancamkan mempunyai pembatasan yang bertujuan untuk melindungi dan memberikan upaya rehabilitasi kepada pelaku yang dijatuhi pidana. Indikator utama yang sering digunakan untuk menunjukkan bahwa terpidana dimaksudkan untuk mendapatkan pembinaan

\footnotetext{
${ }^{13}$ Hasil wawancara dengan Maroni, Akademisi Hukum Pidana Fakultas Hukum Unila. Sabtu 7 November 2015.

${ }^{14}$ Ibid.
} 
adalah dengan adanya perbaikan dari diri terpidana atau terpidana dinyatakan berkelakuan baik. Tujuan pemidanaan yang menekankan pada rehabilitasi atau pembinaan terhadap terdakwa terdapat dalam beberapa ketentuan pengurangan pemidanaannya. Terhadap terpidana yang mendapatkan hukuman penjara seumur hidup, dapat memperoleh keringanan hukuman menjadi 15 tahun apabila terpidana telah menjalani hukumannya selama 10 tahun dan dengan berkelakuan baik.

Pertanggungjwaban pidana apabila dilihat dari orangnya, maka unsur yang harus diperhatikan adalah unsur kemampuan bertanggungjawab. Seseorang yang mampu bertanggungjawab harus dipertanggungjawabkan atas perbuatan yang dilakukannya dan dinyatakan bersalah, oleh karena itu dipidananya seseorang yang melakukan perbuatan tergantung apakah dalam melakukan perbuatan ini dia mempunyai kesalahan atau tidak.

Kemampuan orang untuk membeda-bedakan antara perbuatan yang baik dan yang buruk didasarkan atas kemampuan faktor akal, yaitu orang itu dapat membedakan perbuatan yang diperbolehkan dan perbuatan yang dilarang. Kemampuan untuk menentukan kehendaknya menurut keinsyafan tentang baik buruknya perbuatan tersebut adalah merupakan faktor perasaan yaitu dapat menyesuaikan tingkah lakunya dengan keinsyafan atas mana yang diperbolehkan dan mana yang tidak. Sebagai konsekuensinya adalah orang yang tidak mampu menentukan kehendaknya menurut keinsyafan tentang baik atau buruknya suatu perbuatan, maka dia tidak mempunyai kesalahan bila dia melakukan tindak pidana, orang demikian itu tidak dapat dipertanggungjawabkan.

Penjelasan di atas sesuai dengan ketentuan Pasal 44 Ayat (1) KUHP: "Barangsiapa melakukan perbuatan yang tidak dapat dipertanggungjawabkan kepadanya karena jiwanya cacat dalam pertumbuhan atau terganggu karena cacat, tidak dipidana". Bila tidak dipertanggungjawabkan itu disebabkan hal lain, misalnya jiwanya tidak normal dikarenakan dia masih muda, maka pasal tersebut tidak dapat dikenakan apabila hakim akan menjalankan Pasal 44 KUHP, maka sebelumnya harus memperhatikan apakah telah dipenuhi dua syarat:

1) Syarat psikiatris, yaitu pada terdakwa harus ada kurang sempurna akalnya atau sakit berubah akal, yaitu keadaan kegilaan (idiote), yang mungkin ada sejak kelahiran atau karena penyakit jiwa dan keadaan ini harus terusmenerus.

2) Syarat psikologis ialah gangguan jiwa itu harus pada waktu si pelaku melakukan perbuatan pidana, oleh sebab itu suatu gangguan jiwa yang timbul sesudah peristiwa tersebut, dengan sendirinya tidak dapat menjadi sebab terdakwa tidak dapat dijatuhi pidana.

Berdasarkan uraian di atas maka penulis dapat menganalisis bahwa pertanggungjawaban pidana terhadap pelaku tindak pidana Pemilu Legislatif 
Tahun 2014 didasarkan dengan adanya unsur kesalahan dan kesengajaan dalam melakukan perbuatan pidana, kemampuan terdakwa untuk bertanggungjawab, tidak ada alasan pembenar dan pemaaf bagi terdakwa dalam melakukan tindak pidana Pemilu Legislatif, yaitu dengan sengaja melakukan penambahan suara kepada Peserta Pemilu tertentu. Majelis hakim menjatuhkan pidana kepada para terdakwa oleh karena itu dengan pidana penjara selama 3 (tiga) bulan, dan denda sebesar Rp500.000,- (lima ratus ribu rupiah) dengan ketentuan apabila denda tersebut tidak dibayar maka diganti dengan pidana kurungan selama 1 (satu) bulan .

Menurut penulis, sebaiknya pemidanaan terhadap pelaku tindak pidana Pemilu pada masa yang akan datang tidak hanya diterapkan kepada penyelenggara Pemilu Legislatif (anggota PPK atau anggota KPUD) sebagai pelakunya, tetapi juga kepada pihak-pihak yang diuntungkan dengan adanya tindak pidana tersebut, khususnya peserta Pemilu Legislatif (calon anggota legislatif). Hal ini didasarkan pada asumsi bahwa pada umumnya tindak pidana yang dilakukan adalah dengan sengaja melakukan penambahan suara pada peserta pemilu tertentu, sebagaimana dimaksud dalam Pasal 309 dan Pasal 287 Undang-Undang Nomor 8 Tahun 2012 tentang Pemilihan Umum Anggota Dewan Perwakilan Rakyat, Dewan Perwakilan Daerah, dan Dewan Perwakilan Rakyat Daerah.

Penyelenggara Pemilu Legislatif pada satu sisi melakukan tindak pidana sebagaimana dimaksud Pasal 309 dan Pasal 287 Undang-Undang Nomor 8 Tahun 2012, sementara itu pada sisi lain peserta pemilu menjadi diuntungkan dengan adanya penambahan suara yang dilakukan oleh penyelenggara Pemilu tersebut. Aparat penegak hukum semestinya dapat mengidentifikasi adanya korelasi antara pelaku tindak pidana sebagai pelaku dengan peserta pemilu sebagai pihak yang diuntungkan atas adanya tindak pidana tersebut. Hal ini penting untuk dilakukan mengingat secara logis jenis tindak pidana ini mengindikasikan adanya hubungan sebab akibat antara pelaku tindak pidana dengan pihak yang diuntungkan dari adanya tindak pidana tersebut. Aparat penegak hukum dalam hal ini dituntut untuk cermat dalam menentukan jenis tindak pidana untuk menjerat peserta Pemilu yang diuntungkan dari adanya tindak pidana oleh penyelenggara pemilu, mengingat Undang-Undang Nomor 8 Tahun 2012 belum secara definitif mengatur hal tersebut.

\section{Dasar Pertimbangan Hukum Hakim dalam Menjatuhkan Pidana Terhadap Pelaku Tindak Pidana Pemilu Legislatif Tahun 2014}

Seorang hakim dalam hal menjatuhkan pidana kepada terdakwa harus didasarkan pada berbagai pertimbangan, yang meliputi unsur pertimbangan yuridis, filosofis dan sosiologis. Dasar pertimbangan hukum hakim dalam 
menjatuhkan pidana terhadap pelaku tindak pidana Pemilu Legislatif Tahun 2014 sesuai dengan unsur-unsur tersebut sebagai berikut:

\section{a. Pertimbangan Yuridis}

Hakim secara yuridis, tidak boleh menjatuhkan pidana tersebut kecuali apabila dengan sekurang-kurangnya dua alat bukti yang sah, sehingga hakim memperoleh keyakinan bahwa suatu tindak pidana benarbenar terjadi dan terdakwalah yang bersalah melakukannya (Pasal 183 KUHAP). Alat bukti sah yang dimaksud adalah: (a). Keterangan Saksi; (b). Keterangan Ahli; (c). Surat; (d). Petunjuk; (e). Keterangan Terdakwa atau hal yang secara umum sudah diketahui sehingga tidak perlu dibuktikan (Pasal 184) ${ }^{15}$

Perihal putusan hakim atau putusan Pengadilan merupakan aspek penting dan diperlukan untuk menyelesaikan perkara pidana. Dengan demikian dapat dikonklusikan lebih jauh bahwasannya putusan hakim di satu pihak berguna bagi terdakwa guna memperoleh kepastian hukum tentang statusnya dan sekaligus dapat mempersiapakan langkah berikutnya terhadap putusan tersebut dalam arti dapat berupa menerima putusan, melakukan upaya hukum verzet, banding, atau kasasi, melakukan grasi dan sebagainya. ${ }^{16}$

Putusan hakim merupakan puncak dari perkara pidana, sehingga hakim harus mempertimbangkan aspek-aspek lainnya selain dari aspek yuridis, sehingga putusan hakim tersebut lengkap mencerminkan nilai-nilai sosiologis, filosofis, dan yuridis. Pada hakikatnya dengan adanya pertimbangan-pertimbangan tersebut diharapkan nantinya dihindari sedikit mungkin putusan hakim menjadi batal demi hukum (van rechtswege nietig atau null and void) karena kurang pertimbangan hukum (onvoldoende gemotiverd). Praktik peradilan pidana pada putusan hakim sebelum pertimbangan-pertimbangan yuridis dibuktikan, maka hakim terlebih dahulu akan menarik fakta-fakta dalam persidangan yang timbul dan merupakan konklusi kumulatif dari keterangan para saksi, keterangan terdakwa, dan barang bukti yang diajukan dan diperiksa di persidangan. ${ }^{17}$

Hakim sebagai pelaksana dari kekuasaan kehakiman mempunyai kewenangan dalam peraturan perundang-undangan yang berlaku, dan hal ini dilakukan oleh hakim melalui putusannya. Fungsi utama dari seorang hakim adalah memberikan putusan terhadap perkara yang diajukan kepadanya, di mana dalam perkara pidana, hal itu tidak terlepas dari sistem pembuktian negatif, yang pada prinsipnya menetukan bahwa suatu hak atau peristiwa

\footnotetext{
${ }^{15}$ Rahardjo, Satjipto. Loc Cit.

${ }^{16}$ Mulyadi, Lilik. Op. Cit., p. 120.

${ }^{17}$ Ibid., p. 121.
} 
atau kesalahan dianggap telah terbukti, di samping adanya alat-alat bukti menurut undang-undang juga ditentukan keyakinan hakim yang dilandasi dengan integritas moral yang baik. ${ }^{18}$

Menurut F.X. Supriyadi, kebebasan hakim dalam memeriksa dan mengadili suatu perkara merupakan mahkota bagi hakim dan harus tetap dikawal dan dihormati oleh semua pihak tanpa kecuali, sehingga tidak ada satu pihak yang dapat menginterpensi hakim dalam menjalankan tugasnya tertentu. Hakim dalam menjatuhkan putusan harus mempertimbangkan banyak hal, baik itu yang berkaitan dengan perkara yang sedang diperiksa, tingkat perbuatan dan kesalahan yang dilakukan pelaku, kepentingan pihak korban, keluarganya dan rasa keadilan masyarakat. ${ }^{19}$

Beberapa dasar pertimbangan yuridis hakim dalam proses peradilan pada Putusan Nomor: 70/Pid/2014/PT.TK adalah sebagai berikut:

Majelis Hakim telah membaca Akta permintaan banding Nomor: 581/Pid.Sus/2014/PN.Tjk. yang dibuat oleh Panitera Pengadilan Negeri Tanjungkarang, menerangkan bahwa pada hari Rabu Tanggal 11 Juni 2014, Kuasa Hukum para terdakwa telah mengajukan permintaan banding terhadap putusan tersebut, permintaan banding mana telah diberitahukan kepada Penuntut Umum dengan cara yang sah dan seksama pada hari Rabu Tanggal 11 Juni 2014 sebagaimana tercatat dalam Akta pemberitahuan banding Nomor 581/ Pid.Sus/2014/PN.Tjk

Telah membaca memori banding para terdakwa Tanggal 16 Juni 2014 yang diterima oleh Panitera Pengadilan Negeri Tanjungkarang pada hari Senin Tanggal 16 Juni 2014 dan memori banding tersebut telah diberitahukan kepada Jaksa Penuntut Umum pada hari Senin Tanggal 16 Juni 2014 sebagaimana tercatat dalam Akta pemberitahuan memori banding Nomor 581/Pid.Sus/2014/PN.Tjk;

Menimbang, bahwa terhadap memori banding dari para terdakwa tersebut, Jaksa Penuntut Umum mengajukan kontra memori banding tertanggal Juni 2014 yang diterima di Kepaniteraan Pengadilan Negeri Tanjungkarang pada hari Rabu Tanggal 18 Juni 2014 ; Menimbang, bahwa permintaan banding oleh para terdakwa tersebut telah diajukan dalam tenggang waktu dan menurut cara serta memenuhi syarat-syarat yang ditentukan oleh undang-undang, maka permintaan banding tersebut dapat diterima;

Menimbang, bahwa Terdakwa di dalam memori bandingnya mengajukan keberatan terhadap penjatuhan hukuman dan tidak sependapat dengan pertimbangan Hukum Majelis Hakim tingkat pertama dengan alasan

\footnotetext{
${ }^{18}$ Ibid., p. 121.

${ }^{19}$ Hasil Wawancara dengan F.X. Supriyadi. Hakim Pengadilan Negeri Tanjung Karang. Sabtu 31 Oktober 2015.
} 
bahwa Judex Factie dalam putusannya tersebut telah menyebutkan terdakwa dinyatakan bersalah melakukan tindak pidana sebagaimana yang didakwakan Jaksa Penuntut Umum sehingga para terdakwa harus dijatuhi pidana sesuai dengan peraturan perundang-undangan yang berlaku serta sesuai pula dengan rasa keadilan dalam putusannya. Perbedaan sudut pandang terjadi pada pertimbangan yang satu dengan lainnya dapat mempengaruhi berat ringannya hukuman yang dijatuhkan pada diri para terdakwa.

Menimbang, bahwa setelah Majelis Hakim Pengadilan Tinggi membaca, meneliti dan mempelajari dengan seksama berkas perkara dan salinan resmi putusan, memori banding dari para terdakwa serta kontra memori banding Jaksa Penuntut Umum, Majelis Hakim Pengadilan Tinggi berpendapat bahwa putusan Pengadilan Negeri Tanjungkarang Tanggal 10 Juni 2014 Nomor: 581/PID.SUS/2014/PN.Tjk; patut diperbaiki sekedar mengenai lamanya pemidanaan (straf maad).

Menimbang, bahwa Majelis Hakim Tinggi tidak sependapat mengenai pemidanaan (straf maad) pidana yang dijatuhkan pada diri para terdakwa terlalu berat, mengingat perbuatan yang dilakukan tidak dilakukan secara massif dan terstruktur, sehingga menurut Majelis Hakim Tinggi putusan pidana yang akan dijatuhkan dalam amar putusan ini dirasa cukup adil.

Menimbang, bahwa berdasarkan alasan-alasan dan pertimbangan tersebut di atas, maka putusan Pengadilan Negeri Tanjungkarang Tanggal 10 Juni 2014 Nomor: 581/Pid.SUs/2014/PN.Tjk. yang dimintakan banding tersebut patut untuk diperbaiki sekedar mengenai lamanya pemidanaan (strafmaad);

\section{b. Pertimbangan Filosofis}

Pertimbangan filosofis merupakan salah satu unsur dalam pertimbangan hakim, yaitu hakim mempertimbangkan bahwa pidana yang dijatuhkan kepada terdakwa merupakan upaya untuk memperbaiki perilaku terdakwa melalui proses pemidanaan. Hal ini bermakna bahwa filosofi pemidanaan adalah pembinaan terhadap pelaku kejahatan sehingga setelah terpidana keluar dari lembaga pemasyarakatan, akan dapat memperbaiki dirinya dan tidak melakukan kejahatan lagi.

Keseluruhan jalannya proses peradilan pada akhirnya akan bermuara pada penjatuhan putusan oleh hakim. Dalam proses perumusan putusan itulah menjadi persoalan yang sangat penting merupakan proses legal reasoning dalam merumuskan apa yang menjadi isu hukum utama atau esensi pokok dalam perkara tersebut, karena atas dasar itulah selanjutnya hakim menentukan bagian yang terpenting dalam putusan pengadilan yaitu ratio decendi. Ratio decidendi merefleksikan analisis kritis terhadap substansi perkara, pandangan filsafat hukum, paham atau teori hukum yang 
dirujuk, interpretasi norma, serta dasar hukum yang digunakan sebagai dasar putusan. Penalaran hukum serta perumusan argumentasi hukum dalam proses perumusan putusan, akan menggambarkan bagaimana kesungguhan dan kecermatan majelis hakim ketika hendak menentukan isi putusannya. Proses perumusan putusan hakim bukanlah sekedar persoalan mencari kesesuaian antara rumusan kaidah hukum dengan fakta persidangan. Melainkan merupakan proses ijtihad dan pergulatan batin sekaligus dialog spiritual transendental antara hakim dengan Tuhannya tentang putusan yang bagaimana yang seharusnya akan dijatuhkannya. Dalam proses demikian diharapkan terjadi pencerahan batin bagi hakim yang bersangkutan.

Beberapa dasar pertimbangan filosofis hakim dalam proses peradilan pada Putusan Nomor: 70/Pid/2014/PT.TK adalah menurut hemat Majelis Hakim Tinggi terhadap diri para terdakwa, patut dan adil kiranya apabila dijatuhi hukuman pidana bersyarat sesuai ketentuan pasal 14 a KUHPidana untuk memberikan pelajaran hidup baginya.

\section{c. Pertimbangan Sosiologis}

Dasar pertimbangan hakim secara sosoiologis dalam menjatuhkan pidana pada Anggota PPK Kecamatan Tumijajar dan Tulang Bawang Tengah sebagai pelaku tindak pidana pemilu legislatif dalam Putusan Nomor: 70/Pid/2014/PT.TK, terdiri dari hal-hal yang memberatkan dan halhal yang meringankan, yaitu sebagai berikut:

1) Hal yang memberatkan yaitu perbuatan para terdakwa sebagai penyelenggara pemilu telah menciderai pelaksanaan demokrasi

2) Hal-hal yang meringankan, yaitu:

a) Terdakwa mengakui perbuatannya dan belum pernah dihukum

b) Terdakwa memiliki tanggungan keluarga

c) Terdakwa sopan dalam persidangan

Majelis Hakim dalam menentukan pidana terhadap pelaku tindak pidana pemilu legislatif, memiliki beberapa pertimbangan baik yang memberatkan maupun meringankan hukuman terhadap pelaku tindak pidana pemilu legislatif. Kekuasaan kehakiman sebagai suatu badan yang menentukan dan kekuatan kaidah-kaidah hukum positif dalam konkretisasi oleh hakim melalui putusannya. Bagaimanapun baiknya segala peraturan perundang-undangan yang diciptakan dalam suatu negara, dalam usaha menjamin keselamatan masyarakat menuju kesejahteraan rakyat, peraturanperaturan tersebut tidak ada artinya, apabila tidak ada kekuasaan kehakiman yang bebas dengan diwujudkan dalam bentuk peradilan yang bebas dan tidak memihak, sebagai salah satu unsur negara hukum. ${ }^{20}$

${ }^{20}$ Ibid., p. 124. 
Putusan hakim merupakan hasil dari kewenangan mengadili setiap perkara yang ditangani dan didasari pada Surat Dakwaan dan fakta-fakta yang terungkap di persidangan dan dihubungkan dengan penerapan dasar hukum yang jelas, termasuk di dalamnya berat ringannya penerapan pidana penjara sesuai asas hukum pidana yaitu asas legalitas yang diatur pada Pasal 1 Ayat (1) KUHP yaitu Hukum Pidana harus bersumber pada undangundang, artinya pemidanaan haruslah berdasarkan Undang-Undang. Terkait hakim yang menjatuhkan pidana minimal terhadap terdakwa, menurut penulis hal tersebut tidak selamanya dapat diterapkan karena berpotensi menjadi yurisprudensi di masa-masa yang akan datang, namun demikian Undang-Undang Kekuasaan Kehakiman mengatur bahwa putusan hakim bersifat independen dan harus bebas dari intervensi dari pihak manapun, dalam kondisi yang demikian semua putusan hakim harus memenuhi rasa keadilan masyarakat.

\section{Penutup}

\section{Simpulan}

Pertanggungjawaban pidana terhadap pelaku tindak pidana Pemilu Legislatif Tahun 2014 didasarkan dengan adanya unsur kesalahan dan kesengajaan dalam melakukan perbuatan pidana, kemampuan terdakwa untuk bertanggungjawab, tidak ada alasan pembenar dan pemaaf bagi terdakwa dalam melakukan tindak pidana Pemilu Legislatif, yaitu dengan sengaja melakukan penambahan suara kepada Peserta Pemilu tertentu. Majelis hakim menjatuhkan pidana kepada para terdakwa oleh karena itu dengan pidana penjara selama 3 (tiga) bulan, dan denda sebesar Rp500.000,(lima ratus ribu rupiah) dengan ketentuan apabila denda tersebut tidak dibayar maka diganti dengan pidana kurungan selama 1 (satu) bulan.

Dasar pertimbangan hukum hakim dalam menjatuhkan pidana terhadap pelaku tindak pidana Pemilu Legislatif Tahun 2014 dalam Putusan Nomor 70/Pid./2014/PT.TJK secara yuridis adalah terpenuhinya alat-alat bukti dalam persidangan sebagaimana dimaksud Pasal 183 dan Pasal 184 KUHAP. Secara filosofis adalah menilai bahwa pidana yang dijatuhkan sebagai upaya pembinaan terhadap perilaku terdakwa. Secara sosiologis terdiri dari hal yang memberatkan yaitu para terdakwa sebagai penyelenggara pemilu telah menciderai pelaksanaan demokrasi dan hal yang meringankan yaitu para terdakwa mengakui perbuatannya dan belum pernah dihukum, memiliki tanggungan keluarga dan sopan dalam persidangan. 


\section{Saran}

a. Kepada Panwaslu, KPU, Kepolisian serta semua pihak yang berkepentingan di dalam Pemilu hendaknya dapat benar-benar melaksanakan tugasnya sesuai yang diamanatkan.

b. Hakim dalam menjatuhkan pidana terhadap penyelenggara Pemilu hendaknya harus benar-benar melihat semua aspek berdasarkan kepastian hukum, kemanfaatan dan keadilan hukum, agar keadilan sebenarbenarnya dapat tercapai dan dapat dirasakan semua pihak.

\section{Daftar Pustaka}

\section{A. Buku}

Hikam, Muhammad A.S. (2002). Politik Kewarganegaraan, Landasan Redemokratisasi di Indonesia. Jakarta: Penerbit Bentara.

Mulyadi, Dedi. (2013). Perbandingan Tindak Pidana Pemilu Legislatif dalam perspektif hukum di Indonesia, Cetakan Kesatu. Bandung: PT Refika Aditama.

Rahman, Arifin. (2006). Sistem Politik Indonesia, Surabaya: SIC.

\section{B. Jurnal}

Tumpa, Harifin A. (2015). "Penerapan Konsep Rechtsvinding dan Rechtsschepping oleh Hakim dalam Memutus Suatu Perkara", Halrev Journal of Law, 1(2).

\section{Peraturan Perundang-Undangan}

Undang-Undang Nomor 1 Tahun 1946 tentang Pemberlakuan Kitab Undang-Undang Hukum Pidana.

Undang-Undang Nomor 8 Tahun 1981 tentang Kitab Undang-Undang Hukum Acara Pidana.

Undang-Undang Nomor 8 tahun 2012 Tentang Pemilihan Umum Anggota Dewan Perwakilan Rakyat, Dewan Perwakilan Daerah, dan Dewan Perwakilan Rakyat Daerah 
